\title{
Major- and Trace-Element Concentrations in Soils from Two Geochemical Surveys (1972 and 2005) of the Denver, Colorado, Metropolitan Area
}

Data Series 299 


\section{Major- and Trace-Element Concentrations in Soils from Two Geochemical Surveys (1972 and 2005) of the Denver, Colorado, Metropolitan Area}

By James E. Kilburn, David B. Smith, L. Graham Closs, and Steven M. Smith

Data Series 299 


\section{U.S. Department of the Interior DIRK KEMPTHORNE, Secretary}

\section{U.S. Geological Survey \\ Mark D. Myers, Director}

\section{U.S. Geological Survey, Reston, Virginia 2007}

For product and ordering information:

World Wide Web: http://www.usgs.gov/pubprod

Telephone: 1-888-ASK-USGS

For product and ordering information:

World Wide Web: http://www.usgs.gov/pubprod

Telephone: 1-888-ASK-USGS

For more information on the USGS - the Federal source for science about the Earth, its natural and living resources, natural hazards, and the environment:

World Wide Web: http://www.usgs.gov

Telephone: 1-888-ASK-USGS

Any use of trade, product, or firm names is for descriptive purposes only and does not imply endorsement by the U.S. Government.

Although this report is in the public domain, permission must be secured from the individual copyright owners to reproduce any copyrighted materials contained within this report.

Suggested citation: Kilburn, J.E., Smith, D.B., Closs, L.G., and Smith, S.M., 2007, Major- and trace-element concentrations in soils from two geochemical surveys (1972 and 2005) of the Denver, Colorado, metropolitan area: U.S. Geological Survey Data Series 299, 5 p. plus data tables.

Although these data have been used by the USGS and have been successfully imported into data base programs, no warranty, expressed or implied, is made by the USGS as to how successfully or accurately the data can be imported into any specific application software running on any specific hardward platform. The fact of distribution shall not constitute any such warranty, and no responsibility is assumed by the USGS in connection therewith.

The U.S. Geological Survey cannot verify the accuracy of the data contained within the electronic files of this report if the data were obtained from a source other than the U.S. Geological Survey. 


\section{Contents}

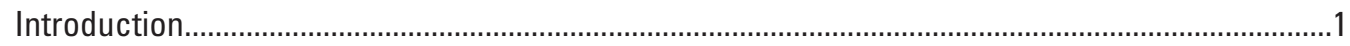

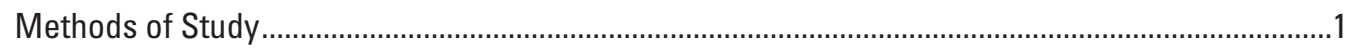

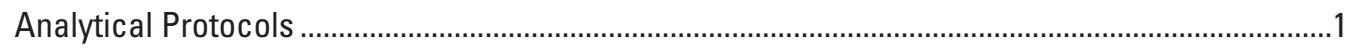

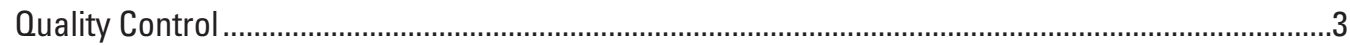

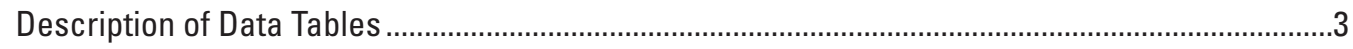

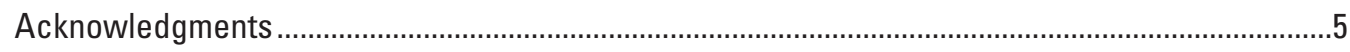

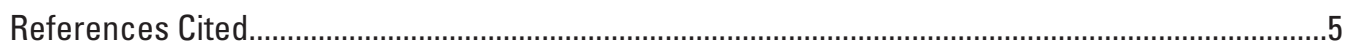

\section{Figures}

1. Location of soil-sampling sites for the 1972 geochemical survey of the

Denver, Colorado, metropolitan area ..............................................................................2

2. Location of soil-sampling sites for the 2005 geochemical survey of the Denver, Colorado, metropolitan area in Denver, Colorado, 2005.

\section{Tables}

1. Elements determined by ICP-MS and ICP-AES with their upper and lower reporting limits. 3

2. Major- and trace-element data for $<250-$ micron soils collected in Denver, Colorado, 1972 ............................................................................... links on page 1

3. Major- and trace-element data for $<250$-micron soils collected in Denver, Colorado, 2005 ..links on page 1

4. Major- and trace-element data for $<2-$ millimeter soils collected in Denver, Colorado, 2005 links on page 1 


\title{
Major- and Trace-Element Concentrations in Soils from Two Geochemical Surveys (1972 and 2005) of the Denver, Colorado, Metropolitan Area
}

\author{
By James E. Kilburn,' David B. Smith,' L. Graham Closs, ${ }^{2}$ and Steven M. Smith ${ }^{1}$
}

\section{Introduction}

This report contains major- and trace-element concentration data for soil samples collected in 1972 and 2005 from the Denver, Colorado, metropolitan area. A total of 405 sites were sampled in the 1972 study from an area approximately bounded by the suburbs of Golden, Thornton, Aurora, and Littleton to the west, north, east, and south, respectively. This data set included 34 duplicate samples collected in the immediate vicinity of the primary sample. In 2005, a total of 464 sites together with 34 duplicates were sampled from the same approximate localities sampled in 1972 as well as additional sites in east Aurora and the area surrounding the Rocky Mountain Arsenal. Sample density for both surveys was on the order of 1 site per square mile. At each site, sample material was collected from a depth of 0-5 inches. Each sample collected was analyzed for near-total major- and trace-element composition by the following methods: (1) inductively coupled plasma-mass spectrometry (ICP-MS) and inductively coupled plasma-atomic emission spectrometry (ICP-AES) for aluminum, antimony, arsenic, barium, beryllium, bismuth, cadmium, calcium, cerium, cesium, chromium, cobalt, copper, gallium, indium, iron, lanthanum, lead, lithium, magnesium, manganese, molybdenum, nickel, niobium, phosphorus, potassium, rubidium, scandium, silver, sodium, strontium, sulfur, tellurium, thallium, thorium, tin, titanium, tungsten, uranium, vanadium, yttrium, and zinc; and (2) hydride generationatomic absorption spectrometry for selenium. The samples collected in 2005 were also analyzed by a cold vapor-atomic absorption method for mercury. This report makes available the analytical results of these studies.

\section{Methods of Study}

In 1972, Skyline Laboratories (Skyline) of Arvada, Colorado, conducted a soil geochemical survey over much of

${ }^{1}$ U.S. Geological Survey, Denver, Colorado.

${ }^{2}$ Colorado School of Mines, Golden, Colorado. the Denver metropolitan area. Sample localities were chosen near the corners of a 1 mile by 1 mile grid that defines sections in the public land survey system (http://www.nationalatlas. gov/articles/boundaries/a_plss.html). This survey system resulted in a sample density of about 1 site per square mile (fig. 1). A total of 405 sites (including 34 duplicates) were sampled. Prior to chemical analyses, the samples were airdried, sieved to less than 250 microns ( -60 mesh), and ground to minus-100 mesh ( $<150$ microns). The samples were then analyzed for copper, lead, zinc, cadmium, and mercury, but the results of this study were never published. In 2005, the archived Skyline samples were obtained by the U.S. Geological Survey (USGS) and Colorado School of Mines (CSM) and reanalyzed by the USGS for 43 elements using contemporary techniques as detailed in the following section. Table 1 shows the elements analyzed and the reporting range for each element. The analytical results are given in table 2. Link to table2.pdf or table2.xls.

In 2005, USGS and CSM revisited and sampled, as near as could be established, the original Skyline sites and additional localities on the eastern periphery of the Denver metropolitan area (fig. 2). Samples were collected at 464 sites including 34 duplicates. Sampling protocols were identical to the 1972 survey in that the top 5 inches of soil was collected for analysis. The soils were air-dried and split into two fractions using a riffle splitter. One of the splits was sieved to $<250$ microns $(-60$ mesh) (fine fraction) to enable a direct comparison with the 1972 Skyline samples. The other split was sieved to $<2$ millimeters $(-10$ mesh) (coarse fraction), which is standard for most current soil studies in both the agricultural and environmental arenas. Both the fine fraction and the coarse fraction were then ground to minus-100 mesh ( $<150$ microns) prior to analysis. The analytical results for the 2005 fine and coarse fractions are given in tables 3 and 4, respectively. Link to table3.pdf or table3.xls and table4.pdf or table4.xls.

\section{Analytical Protocols}

All soil samples from both the 1972 and 2005 surveys were analyzed by the USGS laboratories for 42 major and trace elements by a combination of inductively coupled 


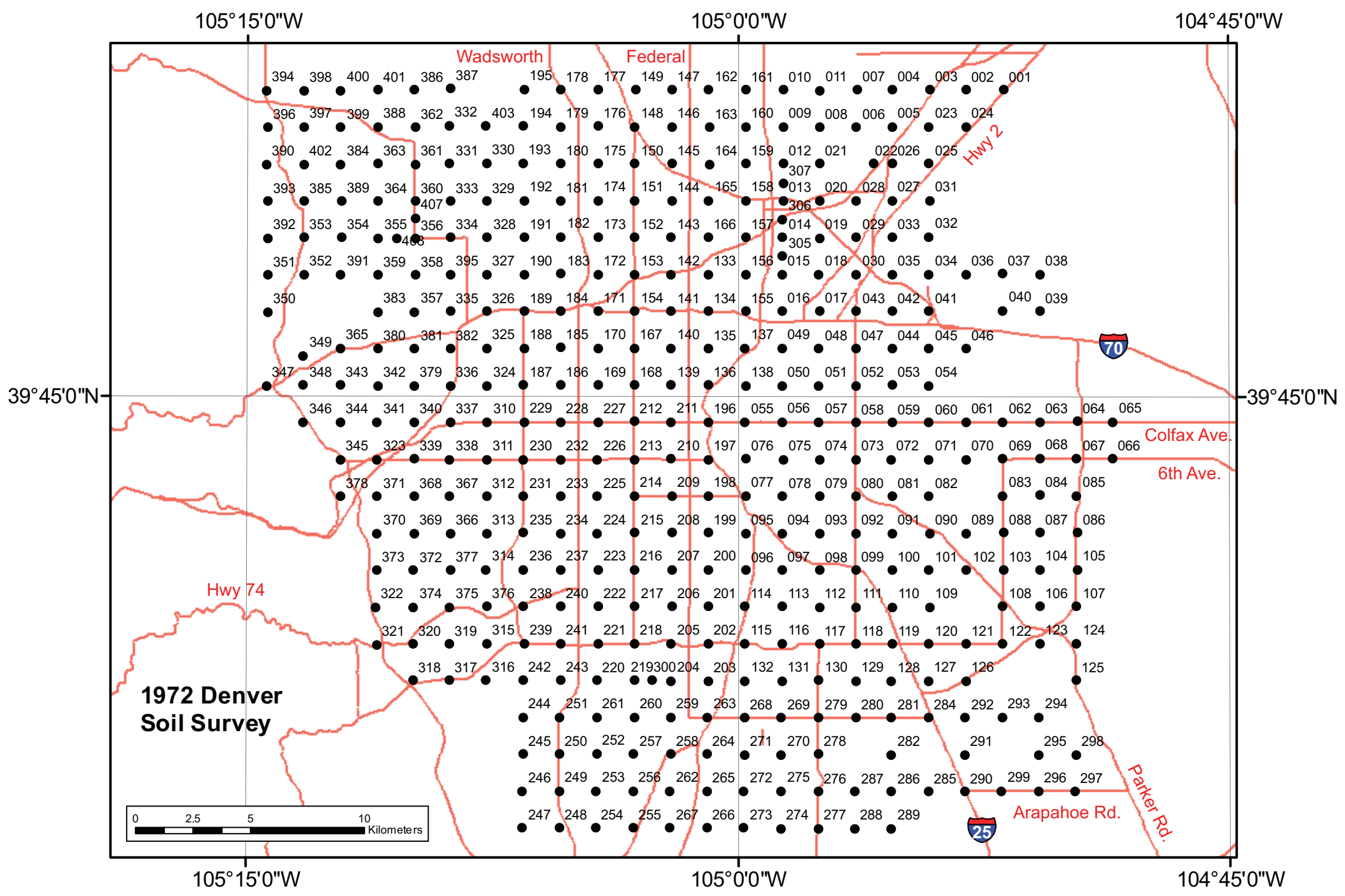

Figure 1. Location of soil-sampling sites for the 1972 geochemical survey of the Denver, Colorado, metropolitan area. 
Table 1. Elements determined by ICP-MS and ICP-AES with their upper and lower reporting limits

[ppm, parts per million; \%, percent]

\begin{tabular}{|c|c|c|}
\hline Element & $\begin{array}{l}\text { Lower } \\
\text { reporting } \\
\text { limit }\end{array}$ & $\begin{array}{c}\text { Upper } \\
\text { reporting } \\
\text { limit }\end{array}$ \\
\hline Aluminum, $\mathrm{Al}$ & $0.01 \%$ & $15 \%$ \\
\hline Calcium, $\mathrm{Ca}$ & $0.01 \%$ & $15 \%$ \\
\hline Iron, $\mathrm{Fe}$ & $0.01 \%$ & $15 \%$ \\
\hline Potassium, K & $0.01 \%$ & $15 \%$ \\
\hline Magnesium, Mg & $0.01 \%$ & $15 \%$ \\
\hline Sodium, Na & $0.01 \%$ & $15 \%$ \\
\hline Phosphorus, $\mathrm{P}$ & $50 \mathrm{ppm}$ & $1 \%$ \\
\hline Titanium, Ti & $0.01 \%$ & $15 \%$ \\
\hline Silver, Ag & $1 \mathrm{ppm}$ & $10 \mathrm{ppm}$ \\
\hline Arsenic, As & $1 \mathrm{ppm}$ & $1 \%$ \\
\hline Barium, Ba & $5 \mathrm{ppm}$ & $1 \%$ \\
\hline Beryllium, Be & $0.1 \mathrm{ppm}$ & $100 \mathrm{ppm}$ \\
\hline Bismuth, Bi & $0.04 \mathrm{ppm}$ & $1 \%$ \\
\hline Cadmium, $\mathrm{Cd}$ & $0.1 \mathrm{ppm}$ & $1 \%$ \\
\hline Cerium, $\mathrm{Ce}$ & $0.05 \mathrm{ppm}$ & $0.10 \%$ \\
\hline Cobalt, Co & $0.1 \mathrm{ppm}$ & $1 \%$ \\
\hline Chromium, $\mathrm{Cr}$ & $1 \mathrm{ppm}$ & $1 \%$ \\
\hline Cesium, Cs & $0.05 \mathrm{ppm}$ & $0.10 \%$ \\
\hline Copper, $\mathrm{Cu}$ & $0.5 \mathrm{ppm}$ & $1 \%$ \\
\hline Gallium, Ga & $0.05 \mathrm{ppm}$ & $500 \mathrm{ppm}$ \\
\hline Indium, In & $0.02 \mathrm{ppm}$ & $0.05 \%$ \\
\hline Lanthanum, La & $0.5 \mathrm{ppm}$ & $0.10 \%$ \\
\hline Lithium, Li & $1 \mathrm{ppm}$ & $5 \%$ \\
\hline Manganese, Mn & $5 \mathrm{ppm}$ & $1 \%$ \\
\hline Molybdenum, Mo & $0.05 \mathrm{ppm}$ & $1 \%$ \\
\hline Niobium, $\mathrm{Nb}$ & $0.1 \mathrm{ppm}$ & $0.10 \%$ \\
\hline Nickel, Ni & $0.5 \mathrm{ppm}$ & $1 \%$ \\
\hline Lead, $\mathrm{Pb}$ & $0.5 \mathrm{ppm}$ & $1 \%$ \\
\hline Rubidium, Rb & $0.2 \mathrm{ppm}$ & $1 \%$ \\
\hline Sulfur, S & $0.01 \%$ & $5 \%$ \\
\hline Antimony, Sb & $0.05 \mathrm{ppm}$ & $1 \%$ \\
\hline Scandium, Sc & $0.1 \mathrm{ppm}$ & $0.10 \%$ \\
\hline Tin, Sn & $0.1 \mathrm{ppm}$ & $0.10 \%$ \\
\hline Strontium, $\mathrm{Sr}$ & $0.5 \mathrm{ppm}$ & $1 \%$ \\
\hline Tellurium, Te & $0.1 \mathrm{ppm}$ & $0.05 \%$ \\
\hline Thallium, Tl & $0.1 \mathrm{ppm}$ & $1 \%$ \\
\hline Thorium, Th & $0.2 \mathrm{ppm}$ & $1 \%$ \\
\hline Uranium, U & $0.1 \mathrm{ppm}$ & $1 \%$ \\
\hline Vanadium, V & $1 \mathrm{ppm}$ & $1 \%$ \\
\hline Tungsten, W & $0.1 \mathrm{ppm}$ & $1 \%$ \\
\hline Yttrium, Y & $0.1 \mathrm{ppm}$ & $1 \%$ \\
\hline Zinc, $\mathrm{Zn}$ & $1 \mathrm{ppm}$ & $1 \%$ \\
\hline
\end{tabular}

plasma-atomic emission spectrometry (ICP-AES) (modification of Briggs, 2002) and inductively coupled plasma-mass spectrometry (ICP-MS) (modification of Briggs and Meier, 2002). The samples were decomposed using a mixture of hydrochloric, nitric, perchloric, and hydrofluoric acids at low temperature. An aliquot of each sample then was aspirated into ICP-MS and ICP-AES instruments.

Selenium was analyzed in soils from both surveys by hydride generation-atomic absorption spectrometry after digestion in a mixture of nitric, hydrofluoric, and perchloric acids (modification of Hageman and Brown, 2002). The reporting range for selenium was $0.2-4$ parts per million. Mercury was analyzed in the 2005 samples by cold vapor-atomic absorption spectrometry following digestion in nitric and hydrochloric acids (modification of U.S. Environmental Protection Agency, 1994) with a lower reporting limit of 0.02 part per million. The 1972 samples were not analyzed for mercury because they had not been stored in a manner that would preserve the original mercury content of the samples.

\section{Quality Control}

The quality assurance program for the study ensured that analytical results were within acceptable limits of precision (the reproducibility of results) and accuracy (the degree of conformity of results for a reference material [RM] having known concentrations). Each laboratory job of 50 samples included blind duplicates of two samples and two blind RMs of known concentration. In addition, between each analytical job, a separate job was analyzed consisting of multiple RMs. Data were considered acceptable if recovery of all elements for the ICP method was \pm 15 percent at five times the lower limit of determination and if the calculated relative standard deviation (RSD) of duplicate samples is no greater than 15 percent. Criteria for mercury and selenium were \pm 20 percent recovery and $\leq 20$ percent RSD for duplicates.

\section{Description of Data Tables}

Tables 2-4 present the analytical results of the soil surveys. Column 1 of the data tables contains the assigned laboratory numbers and column 2 specifies assigned field numbers. Columns in which element headings show the letters "CVAA" are cold vapor-atomic absorption analysis; "Hyd" indicates hydride generation-atomic absorption analyses; and "ICPAES_MS" signifies inductively coupled plasma-atomic emission spectrometry or mass spectrometry.

The exact location of the 1972 sampling sites was only recorded as latitude and longitude of the section corners and not as the precise coordinates of the actual sampling sites. For many sites, the section corner is located in the middle of the intersection of two major roads. In these instances, the location coordinates of the 1972 sites listed in table 2 are only an 


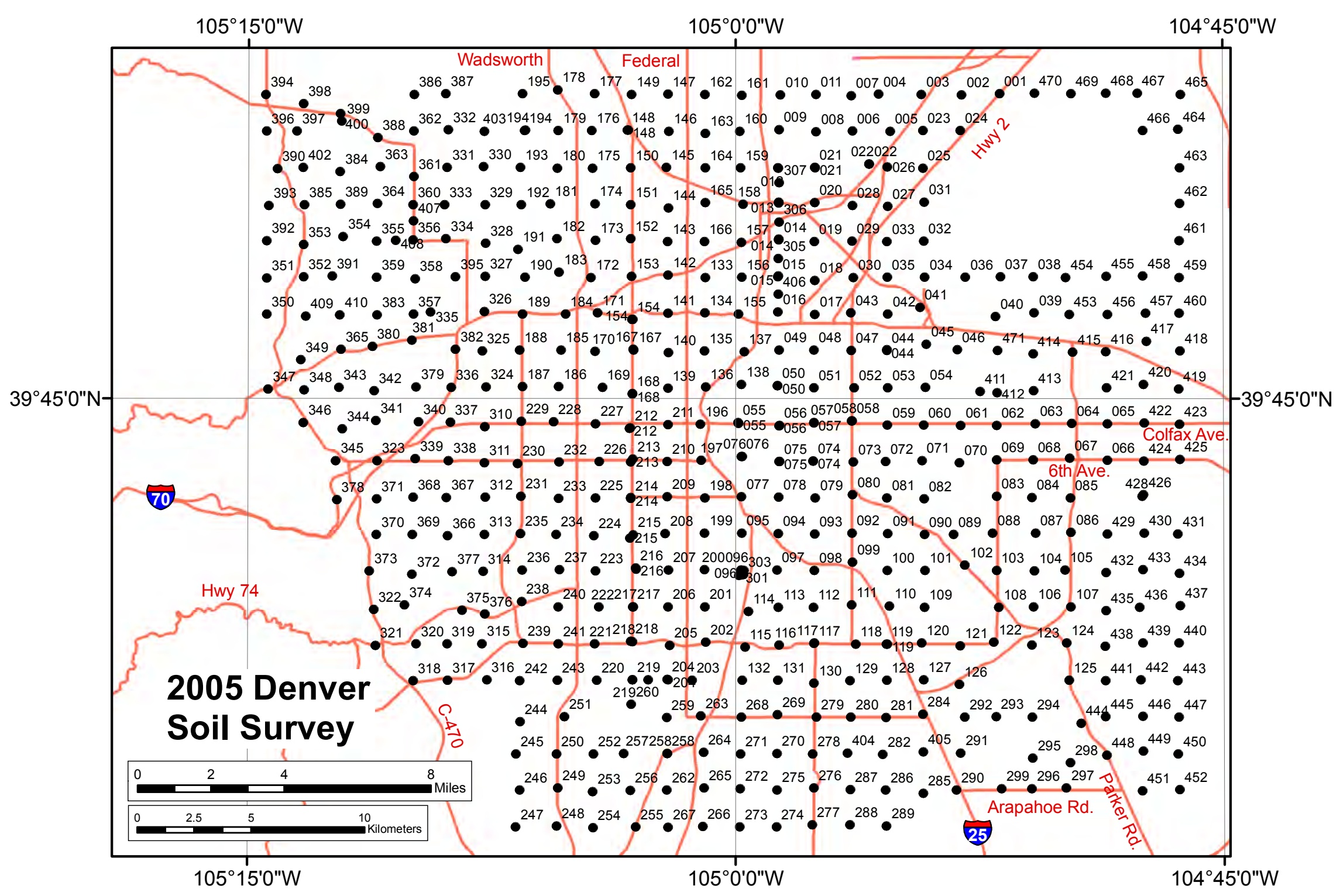

Figure 2. Location of soil-sampling sites for the 2005 geochemical survey of the Denver, Colorado, metropolitan area in Denver, Colorado, 2005 
approximation of where the sample was collected and could differ by as much as $750-1,000 \mathrm{ft}$ from the true sampling site. For the 2005 survey (tables 3 and 4), modern GPS technology was used to accurately locate each site where a sample was collected.

\section{Acknowledgments}

The authors wish to thank Ed Post, past president of Skyline Laboratories, for allowing the USGS access to the 1972 soil samples. We also appreciate the efforts of Allyn Davis, formerly of Skyline Laboratories, who conducted the 1972 soil survey over much of the Denver metropolitan area.

\section{References Cited}

Briggs, P.H., 2002, The determination of forty elements in geological and botanical samples by inductively coupled plasma-atomic emission spectrometry, in Taggart, J.E., ed., Analytical methods for chemical analysis of geologic and other materials, U.S. Geological Survey: U.S. Geological Survey Open-File Report 2002-223, chap. G, 18 p. Available online at URL <http://pubs.usgs.gov/of/2002/ofr-020223/OFR-02-0223.pdf>

Briggs, P.H., and Meier, A.L., 2002, The determination of forty-two elements in geological materials by inductively coupled plasma-mass spectrometry, in Taggart, J.E., ed., Analytical methods for chemical analysis of geologic and other materials, U.S. Geological Survey: U.S. Geological Survey Open-File Report 2002-223, chap. I, 14 p. Available online at URL <http://pubs.usgs.gov/of/2002/ofr-02-0223/ OFR-02-0223.pdf>

Hageman, P.L., and Brown, Z.A, 2002, Arsenic and selenium by flow injection or continuous flow-hydride generationatomic spectrophotometry, in Taggart, J.E., ed., Analytical methods for chemical analysis of geologic and other materials, U.S. Geological Survey: U.S. Geological Survey Open-File Report 2002-223, chap. L, 7 p. Available online at URL <http://pubs.usgs.gov/of/2002/ofr-02-0223/OFR-020223.pdf>

Taggart, J.E., ed., Analytical methods for chemical analysis of geologic and other materials, U.S. Geological Survey: U.S. Geological Survey Open-File Report 2002-223, chap. ZZ, p. 6. Available online at URL <http://pubs.usgs.gov/ of/2002/ofr-02-0223/OFR-02-0223.pdf>

U.S. Environmental Protection Agency, 1994, Method 7471A, Revision 1-Mercury in solid or semisolid waste: EPA SW-846, 1994, 7 p. 